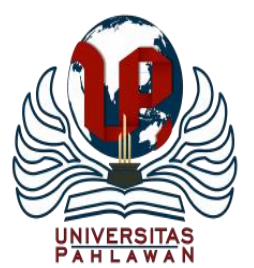

Jurnal Basicedu Volume 4 Nomor 4 Tahun 2020 Halaman 1035-1043

JURNAL BASICEDU

Research \& Learning in Elementary Education

https://jbasic.org/index.php/basicedu

\title{
Pengaruh Model Pembelajaran Inquiry Berbasis Daring Terhadap Hasil Belajar Dan Keterampilan Berargumen pada Muatan Pelajaran IPS di Sekolah Dasar
}

\author{
Leni Rahmawati ${ }^{1}$ Agustina Tyas Asri Hardini $^{2}$ \\ Universitas Kristen Satya Wacana, Jawa Tengah, Indonesia ${ }^{1,2}$ \\ E-mail:292016019@student.uksw.edu,agustina.hardini@uksw.edu
}

\begin{abstract}
Abstrak
Metode penelitian yang digunakan adalah metode Pre Experimental Design. Penelitian ini dilakukan pada satu kelompok yaitu kelompok eksperimen yang mendapat pengajaran dengan menggunakan model pembelajaran Inquiry. Penelitian pada dasarnya adalah usaha pencarian dengan berbasis cara. Metode yang digunakan dalam penelitian ini adalah metode penelitian Pre Experimental Design dengan desain penelitian One Group Pre-testPost-Test. Desain eksperimen dalam penelitian ini menggunakan One Group Pre-Test yaitu desain yang observasinya dilakukan dua kali yaitu sebelum eksperimen disebut Pre Test, dan observasi sesudah eksperimen disebut Post Test. Teknik Analisis data terdiri dari uji prasyarat dan uji hipotesis. Data yang terkumpul dari hasil tes pada kelompok eksperimen dan kelompok kontrol dilakukan pengujian perbedaan rata-rata. Hasil penelitian terdapat perbedaan efektifitas model pembelajaran inquiry berbasis daring terhadap hasil belajar dan keterampilan berargumen pada muatan pelajaran ips kelas V. Simpulan ini didasarkan dari perolehan rata-rata hasil nilai pemahaman konsep siswa pada pretest sebesar 71.190 dengan Uji T 37.730, skor tertinggi yang di capai siswa adalah 75.13 dan skor terendah adalah 67.25. Sedangkan rata-rata hasil nilai pemahaman konsep siswa pada postest setelah diberi perlakuan sebesar 84.762 dengan Uji T 62.447 skor tertinggi yang di capai siswa adalah 87.59 dan skor terendah adalah 81.93.
\end{abstract}

Kata kunci : Pengaruh Model, Inquiry, Daring

\section{Abstract}

The research method used is the Pre Experimental method. This research was conducted in one group, namely an experimental group that learned by using the Inquiry learning model. Research is basically a search effort based on methods. The method used in this study is the Pre Experimental Design research method with the design of One Group Pre-test - Post-Test research. The experimental design in this study used the One Group Pre-Test, a design that was observed twice before the experiment was called the Pre Test, and the follow-up observation of the experiment was called the Post Test. Data analysis techniques consisted of prerequisite tests and hypothesis tests. Data collected from test results in the experimental group and the control group were tested for average variations. Research Results Related to the Effectiveness of Online-Based Inquiry Learning Model on Learning Outcomes and Argumentation Skills in Social Studies Class V content. This conclusion is based on the results of the average assessment results of students in the 71.190 pretest class with 37,730 T-Test, a try score achieved by students is 75.13 and the lowest score is 67.25. While the average value of students' understanding at the posttest after being given a value of 84,762 with T Test 62,447 the highest score achieved by students reached 87.59 and the lowest score was 81.93

Keywords: model influence, inquiry, online

Copyright (c) 2020 Leni Rahmawati Agustina Tyas Asri Hardini

$\triangle$ Corresponding author:

Address : Padang, Sumatera Barat

Email : kukuhvandriani30@gmail.com

ISSN 2580-3735 (Media Cetak)

Phone : 082385327361

ISSN 2580-1147 (Media Online)

DOI: https://doi.org/10.31004/basicedu.v4i4.496 
1036 Pengaruh Model Pembelajaran Inquiry Berbasis Daring Terhadap Hasil Belajar Dan Keterampilan Berargumen pada Muatan Pelajaran IPS di Sekolah Dasar - Leni Rahmawati Agustina Tyas Asri Hardini

DOI: https://doi.org/10.31004/basicedu.v4i4.496

\section{PENDAHULUAN}

Pendidikan mempunyai tugas untuk mempersiapkan sumber daya manusia untuk pembangunan. Semakin baik pendidikan yang ada pada suatu negara, maka kualitas sumber daya manusianya pun semakin meningkat. Kemajuan suatu bangsa tidak terlepas dari pendidikan yang ada. Undang-undang No. 20 Tahun 2003 tentang Sistem Pendidikan Nasional (Sisdiknas), pendidikan itu sendiri adalah usaha sadar dan terencana yang berguna untuk mewujudkan suasana belajar dan proses pembelajaran agar peserta didik dapat mengembangkan potensi yang ada dalam dirinya yang diperlukan dirinya, masyarakat, bangsa dan negara seperti kecerdasan, kekuatan spiritual keagamaan, pengendalian diri, kepribadian, akhlak mulia, dan keterampilan.

Hamalik (2011: 3) mengemukakan pendidikan adalah seperangkat hasil pendidikan yang tercapai oleh siswa setelah diselenggarakannya pendidikan. Pendidikan yang berkualitas perlu diwujudkan untuk mencapai tujuan pendidikan. Tujuan pendidikan seperti tercantum dalam UU N0. 20 Tahun 2003 tentang Sistem Pendidikan Nasional menurut Depdiknas (2003:pasal3) adalah upaya mengembangkan kemampuan dan membentuk watak serta peradaban bangsa yang bermartabat dalam rangka mencerdaskan kehidupan bangsa, bertujuan untuk berkembangnya potensi peserta didik agar menjadi manusia yang beriman dan bertakwa kepada Tuhan Yang Maha Esa, berakhlak mulia, sehat, berilmu, cakap, kreatif, mandiri dan menjadi warga negara yang demokratis serta bertanggung jawab. Hamalik
(2011: 4) berpendapat bahwa pendidikan adalah proses untuk mempengaruhi siswa agar dapat menyesuaikan diri dengan lingkungan disekitarnya. Dengan demikian akan menimbulkan perubahan didalam diri siswa agar dapat bermasyarakat. Pendidikan bertujuan untuk membuat peserta didik mampu mencapai berbagai macam hasil pendidikan setelah proses kegiatan pendidikan. Untuk mencapai berbagai macam tujuan pendidikan dan mempengaruhi siswa agar dapat menyesuaikan diri dengan lingkungan sekitarnya salah satu caranya melalui muatan pelajaran IPS.

Ilmu Pengetahuan Sosial (IPS) merupakan salah satu muatan pelajaran pendidikan yang berupaya untuk mengembangkan pemahaman siswa tentang bagaimana interaksi manusia sebagai individu dan kelompok hidup bersama dengan lingkungannya baik lingkungan fisik maupun lingkungan sosial. Susanto (2014: 7) berpendapat istilah IPS mulai digunakan secara resmi di Indonesia sejak tahun 1975 adalah istilah Indonesia untuk social studies di Amerika. Menurut Trianto (2010: 171) Ilmu Pengetahuan Sosial (IPS) merupakan integrasi dari berbagai cabang ilmuilmu sosial, seperti sosiologi, sejarah, geografi, ekonomi, politik, hukum, dan budaya. Ilmu Pengetahuan Sosial dirumuskan atas dasar realitas dan fenomena sosial masyarakat yang diwujudkan dalam satu pendekatan interdisipliner dari aspek dan cabang-cabang ilmu sosial. IPS atau studi sosial merupakan bagian dari kurikulum sekolah yang diturunkan dari isi materi cabang-cabang ilmu-ilmu sosial yaitu sosiologi, sejarah, geografi, ekonomi, politik, antropologi, filsafat, dan psikologi sosial. 
1037 Pengaruh Model Pembelajaran Inquiry Berbasis Daring Terhadap Hasil Belajar Dan Keterampilan Berargumen pada Muatan Pelajaran IPS di Sekolah Dasar - Leni Rahmawati Agustina Tyas Asri Hardini

DOI: https://doi.org/10.31004/basicedu.v4i4.496

Supardi (2011: 182) mendefinisikan pendidikan IPS di sekolah adalah suatu penyederhanaan disiplin ilmu-ilmu sosial, psikologi, filsafat, ideologi negara dan agama yang diorganisasikan dan disajikan secara ilmiah dan psikologi untuk tujuan pendidikan. Melalui mata pelajaran pengetahuan sosial siswa diarahkan, dibimbing, dan dibantu untuk menjadi warga negara Indonesia dan warga dunia yang baik. Dengan tujuan utama pembelajaran IPS ialah untuk mengembangkan potensi peserta didik agar peka terhadap masalah sosial yang terjadi di masyarakat, dan dapat dengan terampil mengatasi setiap masalah yang terjadi sehari-hari. Pada tingkat SD/MI muatan pelajaran IPS bertujuan agar peserta didik memiliki kemampuan untuk mengenal konsep-konsep yang berkaitan dengan kehidupan di masyarakat dan lingkungannya. Peserta didik memiliki kemampuan dasar untuk berpikir logis dan kritis, rasa ingin tau dan memiliki komitmen dan kesadaran terhadap nilai-nilai sosial. Menurut Djahiri (2006: 13) tujuan IPS ialah membina peserta didik agar mampu mengembangkan pengertian atau pengetahuan berdasarkan generalisasi serta konsep ilmu tertentu maupun yang bersifat interdisipliner atau komprehensif dari berbagai cabang ilmu, mampu mengembangkan dan mempraktekkan keanekaragaman keterampilan studi, memahami dan menghargai adanya keanekaragaman dan kesamaan kultural maupun individu, membina peserta didik untuk berpartisipasi dalam kegiatan kemasyarakatan baik sebagai indivu maupun sebagai warga negara.
Agar siswa dapat mengerti dan juga memahami pelajaran-pelajaran yang diberikan oleh guru, maka guru seharusnya memikirkan serta membuat strategi belajar mengajar yang baik bagi siswa. Maka dari itu diperlukan metode belajar yang sesuai, sehingga akan diperoleh hasil belajar yang diharapkan. Guru harus dapat memotivasi siswa agar dapat terbiasa bekerja mandiri, kreatif dan juga inovatif dalam belajar. Trianto (2010: 51) menyebutkan bahwa model pembelajaran adalah suatu perencanaan atau pola yang digunakan sebagai pedoman dalam merencanakan pembelajaran di kelas atau pembelajaran tutorial. Permendikbud No. 65 (2013: 2) untuk memperkuat pendekatan ilmiah (scientific), tematik terpadu (tematik antar pelajaran), dan tematik (dalam suatu mata pelajaran) perlu diterapkan pembelajaran berbasis penyingkapan atau penelitian (discovery/inquiry learning). Model pembelajaran Inquiry menurut Shoimin (2014: 85) model pembelajaran inquiry merupakan salah satu model pembelajaran yang dapat mendorong siswa untuk selalu aktif dalam pembelajaran, pembelajaran inquiry adalah kegiatan pembelajaran dimana siswa didorong untuk belajar melalui keterlibatan aktif mereka dengan konsep-konsep dan juga prinsipprinsip, serta guru menolong siswa untuk melakukan percobaan yang memungkinkan siswa menemukan prinsip-prinsip untuk diri mereka sendiri. Kunandar (2010: 371)menyatakan bahwa pembelajaran inquiry adalah kegiatan pembelajaran dimana siswa didorong untuk belajar melalui keterlibatan aktif mereka sendiri dengan konsepkonsep dan prinsip-prinsip, dan guru mendorong 
1038 Pengaruh Model Pembelajaran Inquiry Berbasis Daring Terhadap Hasil Belajar Dan Keterampilan Berargumen pada Muatan Pelajaran IPS di Sekolah Dasar - Leni Rahmawati Agustina Tyas Asri Hardini

DOI: https://doi.org/10.31004/basicedu.v4i4.496

siswa untuk memilih pengalaman dan melakukan percobaan yang memungkinkan siswa menemukan prinsip-prinsip untuk diri mereka sendiri. Menurut Ngalimun Dkk (2015: 61) pembelajaran inquiry adalah suatu strategi yang membutuhkan siswa menemukan sesuatu dan mengetahui cara memecahkan masalah dalam suatu penelitian ilmiah. Menurut Trianto (2009: 166) model inquiry merupakan rangkaian kegiatan belajar yang melibatkan secara aktif dan maksimal seluruh kemampuan siswa untuk mencari dan menyelidiki secara sistematis, kritis, logis, analitis, sehingga siswa dapat merumuskan sndiri penemuannya dengan penuh percaya diri. Menurut Kunandar (2010: 371) pembelajaran inquiry adalah kegiatan pembelajaran dimana siswa didorong untuk melajar melalui keterlibatan aktif mereka sendiri dengan konsep dan prinsip, guru mendorong siswa untuk memiliki pengalaman dan melakukan percobaan yang memungkunkan siswa menemukan prinsip untuk diri mereka sendiri. Menurut Sani (2015: 221) pembelajaran inquiry merupakan metode pembelajaran kognitif yang menuntut guru untuk lebih kreatif menciptakan situasi yang dapat membuat siswa lebih aktif menemukan pengetahuannya sendiri.

Adapun langkah-langkah model pembelajaran inquiry menurut Ertikanto (2016: 4445) yaitu yang pertama tahap penyajian masalah. Kedua, tahap pengumpulan dan verivikasi data. Tahap ketiga yaitu tahap pengumpulan data melalui eksperimen. Ke-empat tahap perumusan dan pengolahan data. Kelima yaitu tahap analisis proses inkuiri.
Dalam pelaksanaan model pembelajaran Inquiry terdapat kelebihan dan juga kekurangan. Kelebihan model pembelajaran Inquiy menurut Shoimin (2014: 86) Shoimin antara lain ; a) model inquiry merupakan strategi pembelajaran yang menekankan kepada pengembangan aspek kognitif, afektif dan psikomotor secara seimbang, b) dengan memberikan ruang kepada siswa untuk belajar sesuai dengan gaya belajar mereka, c) merupakan strategi yang dianggap sesuai dengan perkembangan psikologi belajar modern yang menganggap belajar adalah proses perubahan tingkah laku berkat adanya pengalaman, d) dapat melayani kebutuhan siswa yang memiliki kebutuhan diatas rata-rata. Adapun kekurangan pada model pembelajaran Inquiry dalam pelaksanaannya. Kekurangan model pembelajaran inquiry menurut Shoimin (2014:86) antara lain : a) pada pembelajaran ini membutuhkan kecerdasan siswa yang tinggi, b) memerlukan perubahan kebiasaan cara belajar siswa yang menerima informasi dari guru apa adanya, c) guru dituntut mengubah kebiasaan mengajar yang umumnya sebagai pemberi informasi menjadi fasilitator, motivator, dan pembimbing siswa dalam belajar, d) untuk kelas dengan jumlah siswa yang sangat banyak, akan sangat merepotkan guru, e) pembelajaran akan kurang efektif jika guru tidak menguasai kelas.

Menurut Purwanto (2013: 34) hasil belajar merupakan perubahan perilaku siswa akibat belajar. Menurut Nawawi dalam Susanto (2014: 5) menyatakan bahwa hasil belajar dapat diartikan sebagai tingkat keberhasilan siswa dalam 
1039 Pengaruh Model Pembelajaran Inquiry Berbasis Daring Terhadap Hasil Belajar Dan Keterampilan Berargumen pada Muatan Pelajaran IPS di Sekolah Dasar - Leni Rahmawati Agustina Tyas Asri Hardini

DOI: https://doi.org/10.31004/basicedu.v4i4.496

mempelajari materi pelajaran di sekolah yang dinyatakan dengan skor yang diperoleh dari hasil tes mengenai sejumlah materi pelajaran tertentu. Bloom dalam Thobroni ( 2015: 25) menyatakan hasil belajar mencakup kemampuan kognitif, afektif, dan psikomotor. Menurut Dimyati dalam Mudjiono (2013: 3) hasil belajar merupakan hasil dari suatu interaksi tindak belajar dan tindak mengajar. Dari sisi guru, tindak mengajar diakhiri dengan proses evaluasi hasil belajar. Dari sisi siswa, hasil belajar merupakan berakhirnya penggal dan puncak proses belajar. Hasil belajar di pengaruhi oleh beberapa faktor, baik yang bersifat internal maupun eksternal. Menurut Munadi dalam Rusman (2013: 124) faktor-faktor yang mempengaruhi hasil belajar antara lain meliputi faktor internal dan faktor eksternal. Faktor internal meliputi faktor fisiologis dan faktor psikologis. Sementara faktor eksternal meliputi faktor lingkungan dan faktor instrumental.

Dalam pelajaran, siswa dituntut mempunyai kemampuan berargumen di dalam kelas. Sejauh ini, masih banyak siswa yang belum mempunyai kemampuan berargumen dan masih sering melakukan hafalan. Menurut Rahzanie (2011:4) penyebab rendahnya karangan argumentasi siswa terdapat pada media pembelajaran yang kurang dimanfaatkan secara maksimal oleh guru sehingga membuat siswa bosan, dan siswa kurang memiliki wawasan tentang fakta-fakta yang terjadi di sekitar kehidupan mereka. Sehingga karangan yang dihasikan kurang baik dan berbobot. Menurut Amirunsyah et al., ( 2014: 2) ada beberapa faktor yang menyebabkan pembelajaran menulis karangan argumentasi tidak mencapai hasil yang diharap. Faktor tersebut, yaitu (1) siswa belum mampu menulis karangan argumentasi berdasarkan media yang diberikan, (2) siswa belum mampu menemukan data-data dan fakta yang diperlukan untuk menulis, dan (3) siswa belum mampu mengorganisasikan data dan fakta menjadi sebuah paragraf. Tujuan tulisan argumentasi adalah untuk meyakinkan pembaca atas pendapat yang dikemukakan, maka penulis akan menyajikan secara logis, kritis, dan sistematis bukti-bukti yang dapat memperkuat keobjektifan dan kebenaran yang disampaikan sehingga dapat menghapus konflik dan keraguan pembaca terhadap pendapat penulis. Menurut Emidar (2018: 160) argumentasi adalah karangan yang berisi penjelasan, temuan atau keyakinan dengan pemberian alasan, data, dan fakta. Menurut Damayanti (2015: 144) argumentasi adalah karangan yang mengandung argumen atau pendapat, data, dan fakta-fakta yang dapat dibuktikan kebenarannya. Menurut Driver et al (2000) argumentasi yaitu studi tentang bagaimana seseorang dalam situasi tertentu beralasan dari premis ke kesimpulan yang menggunakan penalaran formal dan keterampilan evaluasi. Guru bertanya kepada siswa bukan untuk memperoleh pengetahuan, melainkan untuk memastikan apakah siswa sudah benar-benar paham dengan materi yang telah disampaikan atau belum. Menurut Silberman (2013: 141) debat bisa menjadi metode untuk meningkatkan pemikiran terutama jika siswa diharapkan untuk mengemukakan pendapat yang bertentangan dengan diri mereka. Tujuan penelitian ini adalah untuk mengetahui kemampuan siswa 
1040 Pengaruh Model Pembelajaran Inquiry Berbasis Daring Terhadap Hasil Belajar Dan Keterampilan Berargumen pada Muatan Pelajaran IPS di Sekolah Dasar - Leni Rahmawati Agustina Tyas Asri Hardini

DOI: https://doi.org/10.31004/basicedu.v4i4.496

dalam kecakapan berargumen pada muatan pelajaran IPS SD.

\section{METODE}

Metode penelitian yang digunakan adalah metode Pre Experimental Design. Penelitian ini dilakukan pada satu kelompok yaitu kelompok eksperimen yang mendapat pengajaran dengan menggunakan model pembelajaran Inquiry. Penelitian pada dasarnya adalah usaha pencarian dengan berbasis cara. Tentu saja suatu penelitian membutuhkan suatu metode yang tepat demi tercapainya tujuan dari penelitian. Metode yang digunakan dalam penelitian ini adalah metode penelitian Pre Experimental Design dengan desain penelitian One Group Pre-test - Post-Test. Desain eksperimen dalam penelitian ini menggunakan One Group Pre-Test yaitu desain yang observasinya di lakukan dua kali yaitu sebelum eksperimen disebut Pre Test, dan observasi sesudah eksperimen disebut Post Test. Sampel dalam penelitian ini di ambil dari sebagian populasi dari gugus Hasanudin yaitu siswa kelas V di SD Negeri Mangunsari 02.

Teknik analisis data terdiri dari uji prasyarat dan uji hipotesis. Uji prasyarat terdiri dari uji normalitas dan uji homogenitas. Setelah dilakukannya uji prasyarat kemudian dilaksanakan uji t atau uji beda rata-rata sebagai acuan menguji hipotesis. Analisis data merupakan suatu langkah yang paling menentukan dalam suatu penelitian karena analisis data berfungsi untuk menyimpulkan dari hasil penelitian. Data yang terkumpul dari hasil tes pada kelompok eksperimen dan kelompok kontrol dilakukan pengujian perbedaan rata-rata.
Untuk menguji signifikasi perbedaan rata-rata dengan memakai uji-t yang dilakukan dengan bantuan SPSS 16,0. Pengujian perbedaan rata-rata yang digunakan untuk mengetahui ada tidaknya pengaruh penerapan model pembelajaran Inquiry terhadap kemampuan berargumen dalam pembelajaran IPS.

\section{HASIL DAN PEMBAHASAN}

Tingkat hasil belajar siswa kelas V SD Mangunsari 02 Salatiga dipaparkan melalui statistik deskriptif dari hasil Pretest yang terdiri dari ratarata skor (mean), skor tertinggi (max), dan skor terendah ( $\mathrm{min}$ ), Uji $\mathrm{T}$ yang penyajiannya dalam bentuk grafik. Statistik deskriptif skor Pretest di sajikan dalam tabel berikut:

Tabel 1. Skor Pretest

One-Sample Test

\begin{tabular}{|c|c|c|c|c|c|c|}
\hline & \multicolumn{6}{|c|}{ Test Value $=0$} \\
\hline & \multirow[b]{2}{*}{$\mathrm{T}$} & \multirow[b]{2}{*}{ Df } & \multirow{2}{*}{$\begin{array}{l}\text { Sig. (2- } \\
\text { tailed) }\end{array}$} & \multirow{2}{*}{$\begin{array}{c}\text { Mean } \\
\text { Difference }\end{array}$} & \multicolumn{2}{|c|}{$\begin{array}{c}95 \% \text { Confidence } \\
\text { Interval of the } \\
\text { Difference }\end{array}$} \\
\hline & & & & & Lower & Upper \\
\hline Pretest & 37.730 & 20 & .000 & 71.190 & 67.25 & 75.13 \\
\hline
\end{tabular}

Sumber: Data hasil output SPSS 16,0 for windows, diolah oleh peneliti 2020

Berdasarkan tabel 0.1 diatas dapat dilihat jumlah siswa yang mengikuti Pretest sebanyak 21 siswa. Skor rata-rata sebelum diberi perlakuan sebesar 71.190 dengan Uji T 37.730, skor tertinggi yang di capai siswa adalah 75.13 dan skor terendah adalah 67.25. 
1041 Pengaruh Model Pembelajaran Inquiry Berbasis Daring Terhadap Hasil Belajar Dan Keterampilan Berargumen pada Muatan Pelajaran IPS di Sekolah Dasar - Leni Rahmawati Agustina Tyas Asri Hardini

DOI: https://doi.org/10.31004/basicedu.v4i4.496

Tingkat hasil belajar siswa kelas IV SD Mangunsari 02 Salatiga di paparkan melalui statistik deskriptif dari hasil Postest yang terdiri dari rata-rata skor (mean), skor tertinggi ( $\max$ ), dan skor terendah ( $\mathrm{min})$, Uji $T$ yang penyajiannya dalam bentuk grafik. Statistik deskriptif skor Postest di sajikan dalam tabel berikut.

Tabel 2. Skor Postest

One-Sample Test

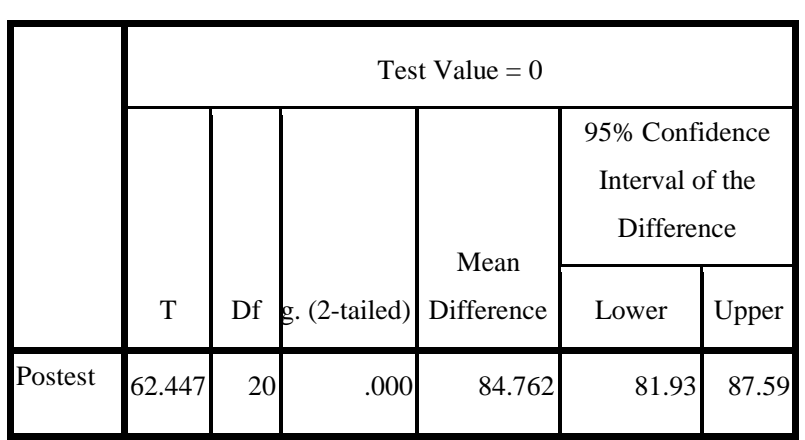

Sumber: Data hasil output SPSS 16,0 for windows, diolah oleh peneliti 2020

Berdasarkan tabel 0.2 diatas dapat dilihat jumlah siswa yang mengikuti Postest sebanyak 21 siswa. Skor rata-rata setelah diberi perlakuan sebesar 84.762 dengan Uji T 62.447 skor tertinggi yang dicapai siswa adalah 87.59 dan skor terendah adalah 81.93 .

Penelitian ini termasuk penelitian preeksperimen. Penelitian ini dilakukan dengan tujuan untuk mengetahui apakah terdapat perbedaan peningkatan kemampuan berargumen pada mupel Ilmu Pengetahuan Sosial dengan menggunakan model pembelajaran Inquiry siswa kelas $\mathrm{V}$ gugus Diponegoro kelurahan mangunsari kecamatan sidomukti kota Salatiga pada tahun ajaran 2019/2020.
Dalam pengambilan keputusan adanya perbedaan pengaruh model pembelajaran Inquiry terhadap hasil belajar dan keterampilan berargumen yang tentunya membutuhkan penilaian. Penilaian pada penelitian ini menggunakan penilaian pretest yang diberikan sebelum perlakuan, dan juga penilaian postest yang diberikan setelah perlakuan. Pada klas V diajarkan dengan materi IPS yaitu kegiatan ekonomi dengan model pembelajaran Inquiry yang diikuti oleh 21 siswa dengan hasil rata-rata postest setelah diberi perlakuan lebih besar dari nilai rata-rata pretest sebelum diberi perlakuan. Maknanya adalah adanya perbedaan yang signifikan dimana pembelajaran dengan model pembelajaran Inquiry memberikan hasil belajar dan kemampuan yang lebih tinggi dari sebelum adanya perlakuan dengan model pembelajaran Inquiry.

Penelitian ini mendukung penelitian Rumakey (2011) dari Universitas Negeri Malang dengan hasil penelitian yang menunjukkan bahwa penerapan model pembelajaran debat cukup efektif. Damayanti (2018) dari Universitas Pendidikan Ganesha dengan hasil penelitian yang menunjukkan bahwa pembelajaran berbasis masalah mampu meningkatkan keterampilan menulis paragraf argumentasi siswa. Hal ini dibuktikan dengan peningkatan aktivitas dan hasil belajar siswa. Namun dalam melaksanakan penelitian ini masih banyak kekurangan atau keterbatasan yang mengakibatkan kurang sempurnanya penelitian ini. Kendala pertama yang dialami adalah keterbatasan dalam pengambilan sampel penelitian dikarenakan adanya pandemi COVID-19 yang sedang terjadi. Kedua proses pembelajaran yang kurang efektif 
1042 Pengaruh Model Pembelajaran Inquiry Berbasis Daring Terhadap Hasil Belajar Dan Keterampilan Berargumen pada Muatan Pelajaran IPS di Sekolah Dasar - Leni Rahmawati Agustina Tyas Asri Hardini

DOI: https://doi.org/10.31004/basicedu.v4i4.496

dikarenakan menggunakan metode daring melalui grup WhatsApp kelas.

\section{SIMPULAN}

Berdasarkan hasil penelitian yang didasarkan pada analisis data maka kesimpulan yang dapat dikemukakan dalam penelitian ini terdapat perbedaan efektifitas model pembelajaran inquiry berbasis daring terhadap hasil belajar dan keterampilan berargumen pada muatan pelajaran ips kelas V Gugus Diponegoro Salatiga. Simpulan ini didasarkan dari perolehan rata-rata hasil nilai pemahaman konsep siswa pada pretest sebesar 71.190 dengan Uji T 37.730, skor tertinggi yang di capai siswa adalah 75.13 dan skor terendah adalah 67.25. Sedangkan rata-rata hasil nilai pemahaman konsep siswa pada postest setelah diberi perlakuan sebesar 84.762 dengan Uji T 62.447 skor tertinggi yang di capai siswa adalah 87.59 dan skor terendah adalah 81.93 .

\section{DAFTAR PUSTAKA}

Amirunsyah, A. A., Idris, A., \& Hatuwe, M. (2014). Implementasi Kebijakan Peran Komite Sekolah SMK Negeri 5 Samarinda. EJournal "Adiministrative Reform", 2(4).

Damayanti, I. (2018). Penerapan model pembelajaran inkuiri untuk meningkatkan hasil belajar mata pelajaran IPA sekolah dasar. Jurnal Penelitian Pendidikan Guru Sekolah Dasar, 2(3), 1-12.

Djahiri, K. (2006). Pengajaran Studi Sosial/IPS (Dasar-Dasar Pengertian, Metodologi, Model Belajar-Mengajar IPS). LPPIPS FKIPS IKIP.

Emidar, E. dan. (2018). Bahasa Indonesia Pengembangan Kepribadian di Perguruan
Tinggi. Rajawali Press.

Ertikanto, C. (2016). Teori Belajar dan Pembelajaran. Media Akademi.

Hamalik, O. (2011). Proses Belajar Mengajar. Bumi Aksara.

Kunandar. (2010). Guru Profesional. Rajawali Press.

Mudjiono. (2013). Belajar dan Pembelajaran. Rineka Cipta.

Ngalimun, \& Dkk. (2015). Strategi dan Model Pembelajaran. Aswaja Presindo.

Permendikbud No 65. (2013). Permendikbud No. 65 Tahun 2013 Tentang Standar Proses Pendidikan Dasar dan Menengah.

Purwanto. (2013). Evaluasi hasil belajar. Pustaka Pelajar.

Rumakey, N. (2011). Penerapan model pembelajaran debat untuk meningkatkan aktivitas dan hasil belajar siswa pada matapelajaran PKn siswa kelas V SDN Lesanpuro 1 Kedungkandang Kota Malang. The Learning University, 2(3).

Rusman. (2013). Metode-Metode Pembelajaran: Mengembangkan Profesionalisme Guru. Raja Grafindo Persada.

Sani, R. A. (2015). Pembelajaran Saintifik untuk Implementasi Kurikulum 2013. Bumi Aksara.

Shoimin, A. (2014). Model Pembelajaran Inovatif Dalam Kurikulum 2013. Ar-Ruz Media.

Silberman, M. (2013). Pembelajran Aktif 101 Strategi untuk Mengajar Secara Aktif. PT Indeks.

Supardi. (2011). Dasar-Dasar Ilmu Sosial. Penerbit Ombak.

Susanto, A. (2014). Teori Belajar dan Pembelajaran di Sekolah Dasa. Kencana Media Group. 
1043 Pengaruh Model Pembelajaran Inquiry Berbasis Daring Terhadap Hasil Belajar Dan Keterampilan Berargumen pada Muatan Pelajaran IPS di Sekolah Dasar - Leni Rahmawati Agustina Tyas Asri Hardini

DOI: https://doi.org/10.31004/basicedu.v4i4.496

Thobroni, M. (2015). Belajar dan Pembelajaran:

Teori dan Praktek. Arr-Ruzz Media.

Trianto. (2009). Mendesain Model Pembelajaran Inovatif Progresif. Kencana Media Group.

Trianto. (2010). Model Pembelajaran Terpadu. Bumi Aksara. 